\title{
Article
}

\section{Titrating medicines to treat neuropathic pain}

Davies, Janice Anne

Available at http://clok.uclan.ac.uk/28934/

Davies, Janice Anne (2019) Titrating medicines to treat neuropathic pain. Journal of Prescribing Practice, 1 (6). p. 276. ISSN 2631-8385

It is advisable to refer to the publisher's version if you intend to cite from the work. 10.12968/jprp.2019.1.6.276

For more information about UCLan's research in this area go to http://www.uclan.ac.uk/researchgroups/ and search for < name of research Group>.

For information about Research generally at UCLan please go to http://www.uclan.ac.uk/research/

All outputs in CLoK are protected by Intellectual Property Rights law, including Copyright law. Copyright, IPR and Moral Rights for the works on this site are retained by the individual authors and/or other copyright owners. Terms and conditions for use of this material are defined in the policies page.

\section{CLoK}

Central Lancashire online Knowledge www.clok.uclan.ac.uk

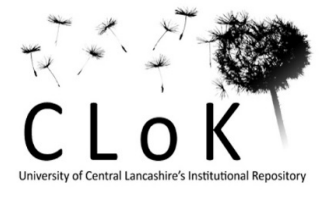


Titrating medicines to treat neuropathic pain

\section{$\underline{\text { ANSWERS }}$}

Several oral medicines that are used in the management of neuropathic pain require dose titration. Calculate the total quantities of medicines that would need to be prescribed for these scenarios:

1. Sean wants to prescribe pregabalin for his patient with neuropathic pain. He wants to start with $75 \mathrm{mg}$ twice daily for 7 days, then increase the dose to $150 \mathrm{mg}$ twice daily. He will be reviewing his patient after 4 weeks. How many $75 \mathrm{mg}$ capsules should be prescribed for 4 weeks?

98

2. Gill wants to prescribe gapapentin for her patient, a 42 year old male. She checks the Summary of Product Characteristics and finds the following dosage advice:

For all indications a titration scheme for the initiation of therapy is described in Table 1 , which is recommended for adults and adolescents aged 12 years and above.

Table 1

\begin{tabular}{|c|c|c|}
\hline \multicolumn{3}{|c|}{ Table 1} \\
\hline \multicolumn{3}{|c|}{ DOSING CHART - INITIAL TITRATION } \\
\hline Day 1 & Day 2 & Day 3 \\
\hline $300 \mathrm{mg}$ once a day & $300 \mathrm{mg}$ two times a day & $300 \mathrm{mg}$ three times a day \\
\hline
\end{tabular}

How many gabapentin 300mg capsules are required for a prescription that will last 2 weeks until she reviews her patient?

39

3. Jawaid is considering prescribing amitriptyline. If the dose was started at $25 \mathrm{mg}$ daily and increased by $25 \mathrm{mg}$ every 3 days to the maximum of $75 \mathrm{mg}$ how many $25 \mathrm{mg}$ tablets would be required for a 2 week prescription?

4. Seema is treating a patient with trigeminal neuralgia and she wants to prescribe carbamazepine. If she starts at $200 \mathrm{mg}$ daily and increases the dose by $100 \mathrm{mg}$ each week up to the usual dose of $200 \mathrm{mg}$ four times a day, how many weeks will it take to reach this dose? 
$\underline{\text { References }}$

Electronic Medicines Compendium (2019) Summary of Product Characteristics (gabapentin $300 \mathrm{mg}$ capsules) Retrieved from:

https://www.medicines.org.uk/emc/product/4636/smpc

Electronic Medicines Compendium (2019) Summary of Product Characteristics (Lyrica capsules) Retrieved from: https://www.medicines.org.uk/emc/product/5539/smpc

Electronic Medicines Compendium (2019) Summary of Product Characteristics (amitriptyline 25mg tablets) Retrieved from: https://www.medicines.org.uk/emc/product/2581/smpc

Electronic Medicines Compendium (2019) Summary of Product Characteristics (Tegretol 100mg tablets) Retrieved from: https://www.medicines.org.uk/emc/product/1040/smpc 